\title{
Current-day matters of administration and law in the field of high-rise construction
}

\author{
Elena Voskresenskaya ${ }^{1,1}$, Vitaly Snetkov ${ }^{1}$ and Alexander Tebryaev ${ }^{1}$ \\ ${ }^{1}$ St. PetersbPeter the Great Saint - Petersburg Polytechnic University, 195251, St. Petersburg, \\ Polytechnicheskaya str., 29, Russia
}

\begin{abstract}
The article touches upon main reasons for high-rise construction: increase in energy consumption and limited availability of site in the big cities of Russia. Increase in energy consumption is related with construction, transportation and applying of ventilation and air conditioning systems. Nowadays, there are developed a lot of design and engineer solutions, that include autonomous systems as well as passive methods with low energy consumption rate, which are interrelated with local climate conditions. Certain architectural solutions contribute to energy consumption decrease: building orientation with respect to the cardinal directions, taking into account the prevailing cold wind directions, maximum glazing of the southern facades and minimum glazing of the northern ones, what plays a big role in hard climate conditions. Limited availability of site for construction in the big cities resulted in rapid development of the high-rise construction, which today prevails in terms of quantitative indicators of civil engineering.
\end{abstract}

\section{Introduction}

A need of regulatory framework arose in the face of development of the high-rise construction in Russia, as the result of the growth of the construction base, investment efficiency, deficiency of territories in a number of cities, as well as its prestige. In accordance with the adopted Act 'On Technical regulation', it is planned to develop technical standards 'On High-Rise Building Safety', a set of rules and Moscow urban construction code for high-rise construction. These documents should reflect those requirements, that are specific for high-rise construction, but absent in the current regulatory framework.

The only regulatory document up to date, that regulates the legislation in this field, is 'Temporary regulations and design rules for multiuse high-rise buildings and complexes in the cities of Moscow and Saint-Petersburg', whereas all existing high-rise construction projects are carried out on the basis of this regulatory document. Despite the status of the document, it doesn't fully meet the needs in terms of high-rise construction design, though 16 design and research institutions were involved to develop these set of regulations. Nowadays, the process of training personnel has been stepped up, the educational programs for "Construction of high-rise buildings and structures" have been opened in leading

\footnotetext{
${ }^{1}$ Corresponding author: elenvoskr@mail.ru
} 
universities of Russia, which allows us to hope to get qualified specialists in the near future. As the result, it will push the process of greater participation of domestic companies in the construction of such objects. That is why the issue of the modern regulatory framework becomes particularly urgent, since the use of foreign experience alone hinders domestic developments in this direction. It should be noted that the role of foreign influence in the regulatory framework for the construction of high-rise buildings is significant. All the fundamental issues related to classifications of objects by their standard functional support, etc., are resolved at meetings of international public organizations of engineers and architects - IABCE - ASCE and CIB. Russia also takes part in the work of these organizations and coordinates its regulatory framework with the requirements of world practices.

\section{Methods}

Current-day matters of administration and law in the field of high-rise construction were studied by the authors of this article [1] and in the works of other authors: Mir V. Ali [2], Potapova Y. I. [3], Markov M. F. [4], Tour V., Markov M., Shcherbach A. [5], Telichenko V.V. [6].

\section{Results}

The main provisions of the energy policy of the Russian Federation are aimed at designing energy-saving comfortable buildings, in which rational architectural and technical solutions are required. Currently, about $40 \%$ of all fuel produced in the country is spent on heating and cooling of buildings, but at the same time, stocks of traditional natural fuels (coal, oil, gas) are gradually depleted both in Russian and throughout the world.

One of the most important problems to solve in high-rise buildings and complexes is their energy efficiency. The energy efficiency of a high-rise building is influenced by such factors as the location of the object, its orientation with respect to the cardinal directions, the functional purpose, the three-dimensional and constructive solution, the applied engineering systems and equipment. The concept of energy efficiency of high-rise buildings is to consider the problem as a single system, including the functioning of buildings and the environment, their mutual influence and interdependence on each other and finding a common, rational path of development.

The limited availability of site for construction in the major cities of Russia, and especially in Moscow and St. Petersburg, was the reason for the rapid development of high-rise construction, which today prevails in terms of quantitative indicators of construction. Multistorey structures are preferably built not only in the segment of residential real estate. The overwhelming majority of business centers today also aspire to the sky with an impressive number of storeys. The big news of the industry come from the sphere of commercial real estate. So, the business world and ordinary people closely follow the development of high-rise business complexes (Moscow City, Lakhta-Center), that significantly affect the urban landscape.

Moscow from a small frontier military point on the site of the village of Kuchkovo for 870 years has turned into the largest in Europe agglomeration area of 13000 to 26000 square $\mathrm{km}$ by 01.01.2017, whereas St. Petersburg from the five historical areas has grown up to 18 . The process of growth of urbanized areas is rapid. According to the UN report, as early as the 1950 s, only 746 million people lived in cities, now it is 3.5 billion. In the next 30 years, the figure will almost double - they predict the number to increase by 2.5 billion. The 
number of megapolises with a population of more than 10 million people rose from 10 in 1990 to 28 in 2014, and in the following 13 years there will be 41 of them.

The construction of skyscrapers, that is conducted in the bedroom suburbs, is mostly welcomed, since it positively influences the development of the uptown districts of the cities. Nevertheless, the construction of large-scale multistorey facilities in downtown of megapolises is ripe for disputes. Thus, the adherents of the traditional architectural style, that prevails in the historical center of the above-mentioned settlements, are skeptical about the construction of such objects and doubt that skyscrapers will harmoniously fit into the cityscape. The defenders of the traditional cityscape of St. Petersburg played a major role in cancellation of the construction of the controversial project "Okhta-Center" on the right bank of the Neva river.

High-rise construction returns in large cities after a 30-year break in the construction of high-rise, mostly administrative, structures. Debates unfold around the new high-rise projects, e.g. the Okhta Center in St. Petersburg. Solution of the problems in construction of specialized (offices, hotels) and multiuse high-rise buildings have to be started almost from scratch. The situation is complicated by the absence of new domestic regulatory framework for the design and construction of high-rise facilities.

In most European countries, building is considered as high-rise, if its height is above $100 \mathrm{~m}$., whereas in the USA - above $150 \mathrm{~m}$. In Russia, buildings above $100 \mathrm{~m}$ are defined high-rise, regardless of their purpose.

Skyscrapers have a distinctive feature - a decrease in unit cost per square meter due to the large number of storeys on one foundation. The more storeys are there in the building, the cheaper construction of each subsequent storey is. About $30-40 \%$ of capital investment in the construction of a skyscraper accrue to the zero cycle (ground works), and the first 6-7 floors of the building. But in all cases we are talking about buildings, which height does not exceed 150-200 meters. When building taller buildings, the cost of construction increases: the more storeys are there in the building, the more expensive the construction of each subsequent floor will be. The scope of work performed by type of economic activity "Construction" in Russia is presented in Table 1.

Table 1. The scope of work performed by type of economic activity "Construction" in Russia

\begin{tabular}{|c|c|c|c|}
\hline \multirow[t]{2}{*}{ Year } & \multirow{2}{*}{$\begin{array}{l}\text { million. rub. (1992 year - tln. } \\
\text { rub., in actual prices) }\end{array}$} & \multicolumn{2}{|l|}{ In $\%$ to comparable prices } \\
\hline & & To the previous year & to 1990 \\
\hline 1992 & 1.5 & 64.0 & 63.0 \\
\hline 2000 & 203.8 & 113.5 & 36.1 \\
\hline 2005 & 1754.4 & 113.2 & 57.7 \\
\hline 2010 & 4454.1 & 105.0 & 82.8 \\
\hline 2012 & 5714.1 & 102.5 & 89.2 \\
\hline 2013 & 6019.5 & 100.1 & 89.3 \\
\hline 2014 & 6125.2 & 97.7 & 87.3 \\
\hline 2015 & 6148.4 & 95.2 & 83.1 \\
\hline 2016 & 6184.4 & 95.7 & 79.5 \\
\hline
\end{tabular}

The optimal height of the building, in terms of its payback, varies for different countries, and largely depends on the design of the building, its purpose, climatic conditions and taxation in the country.

The average number of floors in multifamily houses under construction is approaching to 16. By August 1, 2017, the average number of storeys of multifamily buildings being built in the Russian Federation amounted to 15.9 floors. The leaders in the average height of construction are Moscow, St. Petersburg and the Ryazan Region. Since November 2015, the average number of storeys of multifamily buildings being built in Russia has increased from 15.5 to 15.9 floors per square meter of the house. 
The leader in terms of the height of construction is still Moscow with an index of 21.3 floors on average per square meter under construction.

From July 2017 to October 2017 the following changes occurred in the TOP-10 regions with the highest average height of buildings under construction. The Ryazan Region, where the average height of the houses under construction was 19.1 floors (in July this figure reached 18.5 floors) was the second largest. St. Petersburg moved from second place to third. Rostov region with an index of 17.8 floors rose from the seventh to the fifth place (the number of storeys in July was 17.7). Perm krai also added some storeys to the average index (it was 17.6, and became 17.8 floors), what resulted in the seventh place among the regions, having risen up a notch. Voronezh region, although added 0.5 floors to the average number of storeys (it was 17.2, became 17.7 floors), retained the ninth position. For the first time the Krasnoyarsk krai came in the top with the average number of storeys in multifamily buildings of 16.9 floors. Lipetsk region left the top. Statistical data on the average number of storeys by region are presented in Table 2.

Table 2. The average number of storeys of building in the top-10 regions of Russia

\begin{tabular}{cr}
\hline Region & Average number of storeys $\mathrm{per}^{2}$ \\
\hline Moscow & 21.3 \\
Ryazan region & 19.1 \\
Saint-Petersburg & 19.1 \\
Sverdlovsk region & 18.7 \\
Rostov region & 17.8 \\
Primorsky krai & 17.8 \\
Perm krai & 17.8 \\
Novosibirsk region & 17.7 \\
Voronezh region & 17.7 \\
Krasnoyarsk krai & 16.9 \\
\hline
\end{tabular}

The largest share of housing construction in Russia today accrue to houses with a height of 13-17 floors: they make up 27\% of the total area of housing under construction. The share of high-rise ( 25 and more floors) residential buildings in the Russian Federation by October 1,2017 is $14.3 \%$. Data on the number of storeys of residential buildings are presented in Table 3.

Table 3. The distribution of the number of storeys in the houses under construction and commissioned for operation

\begin{tabular}{lcrrrrr}
\hline $\begin{array}{c}\text { Number of } \\
\text { storeys }\end{array}$ & \multicolumn{2}{l}{$\begin{array}{l}\text { Under } \\
\text { construction }\end{array}$} & & Dwelling units & \multicolumn{2}{c}{ S, total of dwelling units } \\
\cline { 2 - 7 } & units & $\%$ & units & $\%$ & units & $\%$ \\
\hline $1-3$ & 3763 & 25.1 & 96451 & 4.0 & 4915552 & 4.1 \\
$4-8$ & 2862 & 19.1 & 238058 & 9.8 & 11724627 & 9.8 \\
$9-12$ & 3116 & 20.8 & 499984 & 20.5 & 24619745 & 20.5 \\
$13-17$ & 2631 & 17.2 & 657493 & 27.0 & 32411811 & 27.0 \\
$18-24$ & 1802 & 12.0 & 593128 & 24.3 & 29112724 & 24.3 \\
25 and more & 830 & 5.5 & 352510 & 14.5 & 17197663 & 14.3 \\
\hline Total & 15004 & 100 & 2437624 & 100 & 119982112 & 100 \\
\hline
\end{tabular}

The smallest average number of storeys of multifamily buildings being built is fixed in the Jewish Autonomous Region - 3.0 floors. Multifamily buildings with an average number of storeys of 7 floors are being built in 4 more regions.

The data are presented in Table 4. 
Table 4. The smallest number of storeys of buildings in the regions of Russia

\begin{tabular}{cc}
\hline Region & Average number of storeys per $\mathrm{m}^{2}$ \\
\hline Kamchatka krai & 6.6 \\
the Yamalo-Nenets & 6.5 \\
Autonomous District & \\
Republic of North Ossetia- & 6.1 \\
Alania & 5.5 \\
Nents Autonomous District & \\
Jewish Autonomous & 3.0 \\
Region & \\
\hline
\end{tabular}

According to state construction supervision, in the first half of 2017 supervision was carried out for the construction of 60 unique buildings and structures with a total area of 6 million 101 thousand square meters. In accordance with the Town Planning Code of the Russian Federation the object of capital construction acquires the status of 'unique' in the event if at least one of the following characteristics is provided in its design documentation: a height of more than $100 \mathrm{~m}$; width of spans over $100 \mathrm{~m}$; the presence of a console over 20 $\mathrm{m}$; the penetration of the underground part below the planning mark of the land by more than $15 \mathrm{~m}$. One of the high-rise buildings of a unique residential complex is problematic. It is a 32-storey "Academ-Palace", located at 78, Vernadsky Prospekt. The complex has been being built since 2005. Construction stopped in 2014 because of litigation between the developer "OSC" and the owner of the rights to land - the Moscow State Institute of Radio Engineering, Electronics and Automation. If the developer does not resume the construction of the facility, the Committee may use its right to apply to the arbitration court for liquidation of the company. The most remarkable unique non-residential objects being built in Moscow are the Luzhniki sports arena, the reconstructed Dynamo stadium, the spire of the Russian Foreign Ministry building on Smolenskaya Square, the Moscow City MIBC building complex. The core of the Lakhta-Center tower passed for 380 meters. This means that the St. Petersburg supertall has become the tallest building in Europe. The predecessor is the Moscow East Federation (374 m). In 2018, the gap will be 88 meters.

Stage construction was started in late August 2015, the first major milestone happened less than in a year - in June 27, 2016. The core overcame 147-meter mark and the Lakhta Center became the tallest building in St. Petersburg. A couple of weeks later, the skyscraper overtook the highest building in Belgium Tour du Midi, which is located in Brussels. It is 150 meters and was commissioned for operation in 1967. In the same July, the building became taller than the Maastoren - a high-rise building of $164.75 \mathrm{~m}$ in Rotterdam, the Netherlands, which was built in 2010. The tallest skyscraper of Switzerland - Roche Turm Bau 1, $178 \mathrm{~m}$, which was built in 2015, the building of the Lakhta Center exceeded in August 2016. Then the tallest Swedish Tower Turning Torso of $190 \mathrm{~m}$ was left behind. It is also a newbuild.It was commissioned for operation in 2005. Italy's tallest building, UniCredit Tower in Milan, height - $217.7 \mathrm{~m}$. built in 2012, was outstripped in October 2016. At that time the Tour First - the tallest skyscraper of France after being renovated in 2011, when 72 meters were added to the existing 159 - was overtaken. The Warsaw Palace of Culture and Science was overtaken in November 2016. The constructive height of the palace is $230.7 \mathrm{~m}$, according to the Emporis Skyscraper Award. In January 2017 the Spanish the Torre de Cristal with the height of 250 meters, that was built in 2008, was outstripped. April - the German Commerzbank Tower - 259 m., Built in 1997, was overtaken. And world-known English 'The Shard', the 306-meter tower, that was built in 2013, was left behind. The issues of quality of production of construction and installation works and applied materials, products and structures in the construction of high-rise buildings are crucial in ensuring the reliability and durability of structures and the integrated safety of buildings in general. 


\section{Discussion section}

Modern construction in large cities is characterized by a wide application of new, advanced design solutions, materials, structures and technologies, as well as better qualification of performers and the associated large number of participants in the construction process. Under these conditions, effective control over the timely introduction of technical innovations, strict observance of technological discipline and all requirements for the quality of materials and structures, that are used at work sites, becomes crucial along with competent organization of the process and well-coordinated interactions of performers. In the Committee of State Construction Supervision in Moscow, a special Office for Supervision of the Construction of Unique Buildings and Structures was established. In the first half of 2017, the Department already conducted 281 inspections of the Moscow facilities, that are under construction and were recognized as unique, and 253 tests were carried out on the implemented structures and materials. 1152 violations were found in the course of inspections. Quality control at construction sites of the city is continuously improved. A major contribution to the quality improvement of construction is made by comprehensive inspections, when not only representatives of self-regulating organizations in the construction sector took part, but also experts from research organizations and other supervisory bodies. Data on the availability of fixed assets of construction organizations are presented in Table 5.

Table 5. The fixed assets of organizations, conducting construction activities, as $\%$ of the total

\begin{tabular}{|c|c|c|c|c|c|c|}
\hline & 2005 & 2010 & 2012 & 2013 & 2014 & 2015 \\
\hline $\begin{array}{l}\text { Fixed assets - total, } \\
\text { Which include: }\end{array}$ & 100 & 100 & 100 & 100 & 100 & 100 \\
\hline $\begin{array}{l}\text { Buildings } \\
\text { constructions }\end{array}$ & 36.0 & 39.9 & 35.5 & 36.3 & 37.0 & 40.2 \\
\hline $\begin{array}{l}\text { Machinery and } \\
\text { equipment }\end{array}$ & 42.1 & 41.9 & 43.0 & 40.9 & 40.5 & 38.6 \\
\hline Means of transport & 18.4 & 18.6 & 18.9 & 20.2 & 19.8 & 17.9 \\
\hline $\begin{array}{l}\text { Other types of fixed } \\
\text { assets }\end{array}$ & 3.5 & 3.6 & 2.6 & 2.6 & 2.2 & 3.2 \\
\hline
\end{tabular}

The results of comprehensive inspections revealed a number of typical violations that occur in the construction of high-rise buildings. Such violations, in particular, include the use of obsolete or worn out equipment. The state of equipment by January 1, 2017 is displayed in Table 6 .

Table 6. The presence and condition of the main construction machinery in construction organizations

\begin{tabular}{lrrr}
\hline & Total, thd. & \multicolumn{2}{c}{ Of the total units of machinery, \% } \\
\cline { 3 - 4 } & units & $\begin{array}{r}\text { Machinery with } \\
\text { expired service life }\end{array}$ & $\begin{array}{r}\text { Machinery of foreign } \\
\text { manufacture }\end{array}$ \\
\hline Single-bucket excavators & 11.8 & 33.4 & 71.9 \\
Scrapers & 0.3 & 79.2 & 53.4 \\
Bulldozers & 8.9 & 48.1 & 41.7 \\
Tower cranes & 3.7 & 46.2 & 32.1 \\
Vehicle-mounted cranes & 7.2 & 36.1 & 27.6 \\
Pneumatic wheel-mounted cranes & 1.4 & 43.2 & 58.8 \\
Crawler-mounted cranes & 1.2 & 63.1 & 39.4 \\
Autograders & 4.1 & 45.5 & 30.1 \\
\hline
\end{tabular}

\section{Conclusions}


The development of high-rise construction in Russia highlighted a number of problems that require mandatory consideration and solution: imperfection of the regulatory framework; lack of experience in the design and construction of high-rise complexes; lack of qualified civil engineers; justified town-planning and functional-typological necessity of construction; maximum permissible number of storeys (building height); the correct choice of the structural system, scheme and design solutions, taking into account the prevention of loss of stability of the structure foundation and the structure itself, that leads to collapse of structures; inadmissibility of deviation from the approved design and changes in the number of storeys during the construction process; necessary functional interaction of residential and non-residential buildings and structures with the transport and service infrastructure of the city; required capacity of underground, land and aboveground parking lots for personal transport and their rational location; effective minimization of the threat of external and internal danger of building collapse by creating a special service for safe operation; the required fire and evacuation safety of people in high-rise buildings; rational efficiency of modern engineering solutions for life support and equipment of the building, energy saving and comfort of service.

\section{References}

1. Elena Voskresenskaya Vitaly Snetkov Alexander Tebryaev and Zokhidjon Askarov V 2017 MATEC Web of Conferences 10608055

2. Mir V Ali V 2001 Electronic Journal of Structural Engineering 1 2-14 pp

3. Potapova Y I V 2012 Progress of modern natural sciences 6 14-16 pp

4. Markov M F V 2007 Architecture and construction 1 44-47 pp

5. Tour V Markov M Shcherbach A V 2008 Architecture and construction 2 72$81 \mathrm{pp}$

6. Telichenko V V 2008 High-rise construction 20082 112-122 pp 